\title{
Community Empowerment Based on Local Potential Resources in Bukit Aren Village, Pulubala, Gorontalo Regency
}

\author{
Misran Rahman \\ Universitas Negeri Gorontalo, Gorontalo, Indonesia \\ e-mail: misranrahman@ymail.com
}

\begin{abstract}
With the enactment of Constitution Law No. 6 of 2014 about the Village, the opportunity for every village to be able to develop its potential is more open. The opportunity is supported by the government through the increasing of funding for village development every year. However, the efectivity of improving village management and community empowerment is still a challenge.

Bukit Aren Village, Pulubala, Gorontalo Regency is one of the villages that has a promising, potential resource, but the society has not been optimally empowered. In addition, the access to the village is quite difficult that the marketing of the products from the village is frequently constrained. Therefore it is necessary to have a community empowerment program in Bukit Aren Village.

The purpose of this study is to provide a brief description of the condition of community empowerment in Bukit Aren Village, Pulubala. Furthermore, the method used is descriptive methods and interviews.

Based on the results of interviews to the leaders and residents, it is summed up that community empowerment program suggested to be done by: (i) improvement of sugarcane (aren) cultivation to increase the local economy, (ii) improvement of the people to cultivate the resources through education and training, (iii) land-condition analysis about potential plantation area, (iv) government's attention in fulfilling the infrastructure for access of Bukit Aren Village-the city.
\end{abstract}

Keywords: Community Empowerment, local potential resources.

\section{INTRODUCTION}

The opportunities for every villages to develop its potential has been largely opened by the enactment of Constitution Law number 6 of 2014 about the Village. This is supported by the government through the increasing for funding for village development program every year. The expectation of government for this program is done sufficiently in order to obtain the welfare of the people.

For villages with local potential resources, this policy might help to speed up the development of the village. What these villages need are the support from the government and independence, especially for macro interests such as road infrastructure, schools and others.

Bukit Aren Village, Pulubala has a specifically lot of local potential resources such as palm, corn, coconut as well as its fertile soil. These might give benefit for local people. However, Bukit Aren Village is still not as develop as other villages in Pulubala district, Gorontalo Regency. The result of survey suggested that this is because the community empowerment has not been optimalized yet. Therefore, this article will discuss about the results of research about community empowerment based on local potential resources in Bukit Aren Village, Pulubala district.

The purpose of this study is to obtain a description of community empowerment strategies based on local potential reseources that has been done in Bukit Aren Village Pulubala, Gorontalo Regency.

Empowerment is essentially a process of development, self-reliance, self-help in order to strengthen the bargaining position of lower-level society toward the suppressive forces in all fields and life sectors (Eko, 2002). The concept of village community empowerment can be defined in two ways. First, empowerment is interpreted in the context of putting the community as the subject, where the community is not the goal of beneficiaries which depends on the giving of outsiders such as the government, but as agents or participants who act independently. Doing so in independent way does 
not mean they are out of the responsibility of the government. Provision of public services (health education, housing, transportation and so on) to the community is certainly a duty (obligation) of the government. An independent society as a participant means the opening space and capacity to develop his/her potential-creation, controlling the environment and its own resources, solving problems independently, and contributing to the political process in the country's realm. It means the community participates in the process of development and governance (Sutoro Eko, 2002).

Empowerment is a process of transition from a state of powerlessness to a state of relative control over one's life, destiny, and environment (Sadan, 1997). Furthermore, according to Mubarak (2010) community empowerment can be interpreted as an effort to restore or improve the ability of a community to be able to do in accordance with their dignity and in exercising their responsibilities as members of the community.

In empowerment process approaches, it is more about enabling the implementation of human development. It means the community involvement in development leads more to the participation, not mobilization. Public participation in the formulation of the program makes the community is not merely as a consumer program, but also as a producer since they have participated in the process of making and formulating, so that the community will feel involved in the program and has responsibility for its success and has more motivation for participating in the next stage (Soetomo, 2006).

The regulation of ministy of home affairs (Permendagri RI) Number 7 Year 2007 concerning Community Empowerment Cadres, stated that community empowerment is a strategy used in community development as an effort to realize the capability and independence in the life of society, nation and state (Chapter 1, Verse (8)). The core understanding of community empowerment is a strategy to realize the ability and independence of the community. The following objective of community empowerment is to enable and empower the community especially from poverty and backwardness / gap / helplessness.

As for strategies of empowerment, according to Usman (2004), the applicable strategies are: (1) climate creation (enabling), (2) strengthening power (empowering), and (3) protection. Climate creation strategy basically means creating the condition that enables any potential to develop optimally. In this strategy, one focuses on the recognition that any potential that can be developed properly.
Furthermore, the strategy to strengthen the potential or power of the community can be done by improving the level of education and the degree of health, as well as the access to sources of economic progress such as capital, technology, information, employment, and markets. Lastly, to empower means to protect. In an empowerment process, one must prevent the community to become weaker because of the lack of empowerment against the strong community. Finally, the above strategies continue to be developed in Bukit Aren Village, Pulubala, Gorontalo Regency.

\section{METHODS}

In this study, researcher is guided and promoted by a "conceptual frame work" that connotes the research problem being explored. In the activities, the researcher must have the level of intensity of understanding the concepts and theories to deepen the data or information as the content of the research problems. These concepts and theories are perspectives that serve as guidelines for understanding the various problems or information that arise in the inquiry process that is being carried out by the researcher. The methods used in this research are survey method with qualitative approach. In this study, the researcher conducted interviews and observations of research subjects on the implementation and impact of training results that have been implemented.

The research object is a program that has been implemented by various parties in the framework of community empowerment based on local potential in Bukit Aren Village, Pulubala, Gorontalo Regency. Further research subjects are community leaders of Bukit Aren Village, Village Head and some community members closely related to the strategic development opportunities of Bukit Aren Village.

Data collection was conducted through interviews to research subjects. The approach used in assessing this problem is the approach with the naturalistic inquiry paradigm. By this approach, the collection of information (data) obtained is arranged to be focused and organized in a mindset that the data or information meant to focus on explanation of the problem. The tools used for data collection are observation sheets and interview guides. After the data are collected, the results of the interview will be analyzed qualitatively. After the data are analyzed, the conclusion is made. 


\section{RESULTS AND DISCUSSION}

Desa Bukit Aren is one of the villages in Pulubala district with a population of 700 heads of households (Source data: Desa Bukit Aren office 2017). Furthermore, the education levelare: bachelor degree $=3$ people, diploma 1 and 2 degrees $=2$ people, senior high $=62$ people, junior high $=75$ people, elementary $=507$ people, un-graduated elementary $=478$ people. From the data, it appears that the education level of the people of Bukit Aren is dominated by the elementary and un-graduated elementary school. This is likely to be an obstacle in community empowerment efforts. Furthermore, generally the implementation of empowerment in Bukit Aren Village, according to the results of interviews to community leaders and residents, has been done before.

According to the results of the survey researchers, in Bukit Aren Village there are two most potential resources, which are: the aren palm fields and huge land area of fertile soil. Aren palm can be processed into: (a) alcohol solution, "vinegar acid", and natural sweetener producer (brown sugar). In addition the "core" of palm trees can be processed into sago flour.

Process of palm sugar into alcohol solution is done by sublimation process. The "alcohol" solution is widely used in health. Furthermore, process of the palm into vinegar acid is done by the acidification process. Lastly, process of the palm into a natural sweetener (Red Sugar) with low sugar content is done by traditional processing. Sweetener is widely used as a natural sweetener cake-make as well as for sweetens coffee or tea drinks.

The processing of the "core" of aren palm tree trunks into "sago flour" is used non-productive palm trees. Traditionally the core processing of aren palm tree trunks smoothed and then mashed. The core of tree trunks that have been mashed is brewed in water, filtered, and the result of the filter is infiltrated. The sediment is sago flour from aren palm trees. Therefore, it appears that the aren palm tree has an economic value that can improve the welfare of the community. Furthermore the potential of a vast expanse of land allows people to plant various corps. The survey results also show that many types food crops are planted in the area, include coconut, corn, tomatoes, Lombok (chili), onion and etc.

Efforts to maintain the people of Bukit Aren village are done by empowerment strategies, such as: (1) climate creation, (2) strengthening of power, and (3) protection. In climate creation strategy, researcher suggests to improve the potential resources both the aren palm trees plantation and the plantation of various agricultural commodities in the rest vast landscape land in Bukit Aren Village. It will be optimally developed with the support of facilities and other factors.

Furthermore, the strategy to strengthen the power is more focused one improving the level of education, and the degree of health, as well as access to sources of economic progresses such as capital, technology, information, employment, and markets. The increase of education level in Bukit Aren village is the main effort because the survey results show that the education level of the population is dominated by elementary and un-graduated elementary students. Similarly, improving health status and access to sources of economic progress such as capital, technology, information, employment, and markets have to be done.

Finally, community protection and village asset strategies are very important. In its process, the empowerment should be prevented from become weaker. Nevertheless, the strong part of community has to remain strong to keep its wealth.

Therefore, the efforts suggested to be done in community empowerment of Bukit Aren Village, Pulubala, Gorontalo Regency are maximazing the cultivation aren to increase the economic value of the community. Furthermore, it is necessary to improve the capability of human resource by education and training based on the needs of the community. An analysis of soil condition in Bukit Aren village is also necessary in order to find the opportunity of plant that can be planted Bukit Aren Village. Lastly, government attention especially the fulfillment of infrastructure for access Bukit Aren Village-city is hopefully can be provided.

\section{CONCLUSIONS}

From the results and discussion above, the conclusion are Desa Bukit Aren, Pulubala, Gorontalo Regency, has local potential resources that can be developed. One effort that can be done is to empower the village community. Thus, some efforts that can be done are: (i) increasing aren plantation processing to increase the economy of the community, (ii)i Increasing the capacity of human resources in managing the local potentials through education and training, (ii) Analysis of the land condition to find potential plant-type that can be planted in Bukit Aren Village, (iv) the attention of government as the primary effort to fulfill village 
infrastructure, especially access in and out to the Bukit Aren Village.

\section{REFERENCES}

[1] Nasikun. J (1995). Mencari Suatu Strategi Pembangunan Masyarakat Desa Berparadigma Ganda, dalam Jefta Leibo, Sosiologi Pedesaan. Yogyakarta. Andi Offset.

[2] Suwondo, K. (2005) Civil Society Di Aras Lokal: Perkembangan Hubungan Antara Rakyat dan Negara di Pedesaan Jawa, Yogyakarta : Pustaka Pelajar \& Percik. Permendagri RI Nomor 7 Tahhun 2007 tentang Kader Pemberdayaan Masyarakat, Bandung. Fokus Media.

[3] Usman, S. (2004) Pembangunan dan Pemberdayaan Masyarakat, Yogyakarta. Pustaka Pelajar.

[4] Eko, S. (2002), Pemberdayaan Masyarakat Desa, Materi Diklat Pemberdayaan Masyarakat Desa, yang diselenggarakan Badan Diklat Provinsi Kaltim, Samarinda, Desember 2002. 